\title{
29. BASAL IRON-TITANIUM-RICH SEDIMENTS FROM HOLE 315A (LINE ISLANDS, CENTRAL PACIFIC)
}

\author{
Hugh C. Jenkyns and Ron G. Hardy, Department of Geological Sciences, \\ University of Durham, Great Britain
}

\begin{abstract}
Basal red, blue, and green radiolarian claystones and sandstones (chiefly montmorillonite and illite) of probable Santonian age (Hole $315 \mathrm{~A}$, Line Islands) have a chemistry that differs both from modern and ancient spreading-ridge sediments and from Pacific pelagic clays. Relative to deep-sea Pacific clays, the $315 \mathrm{~A}$ basal sediments are enriched in $\mathrm{Fe}$ and $\mathrm{Ti}$; however, their trace element levels generally are lower. This chemistry roughly matches that of the underlying volcanics. The iron may thus derive from submarine weathering of basalt; the titanium is probably specifically related to the presence of detrital clinopyroxene and authigenic anatase.

The chemistry of these Line Islands sediments is comparable with that of the red claystones lying on the altered volcanics of Meiji Guyot (Emperor Seamounts); the implication is, therefore, that oceanic islands are characterized by a specific type of basal deposit in the genesis of which geothermal systems and "hydrothermal solutions" play a negligible role.
\end{abstract}

\section{INTRODUCTION}

The basal radiolarian-bearing claystones and sandstones (?Santonian) of Hole 315A (Line Islands) aroused considerable interest aboard ship as they were vividly colored in shades of blue, green, and red, and differently colored zones alternated. As these sediments lie just above basaltic basement it was suspected that they might be enriched in $\mathrm{Fe}, \mathrm{Mn}$, and certain trace metals, much as in the deposits described by Boström and Peterson $(1966,1969)$ and Piper (1973) from the East Pacific Rise and many other authors from Deep Sea Drilling cores sampled immediately above oceanic basalt (e.g., von der Borch and Rex, 1970; Drever, 1971; von der Borch et al., 1971; Cook, 1972; Cronan, 1973). Accordingly, major- and minor-element analyses and Xray mineralogical studies were carried out on nine samples of these multicolored deposits.

\section{METHODS}

\section{X-Ray Diffraction}

The qualitative and quantitative mineralogy of the samples was determined by X-ray diffraction techniques. The method used was a modification of that described by Griffin (1954) and Gibbs (1967), in which synthetic boehmite was added as an internal standard.

The X-ray equipment employed was a Philips PW1130 3-kw diffractometer, with a sealed proportional counter, using iron-filtered cobalt radiation at $60 \mathrm{kv} 30$ $\mathrm{mA}$. All smear-oriented specimens were run at a scanning speed of $1^{\circ}$ of $2 \theta$ per min over the required angular range. Several samples were subjected to specialized Xray investigation as well as quantitative mineralogical analyses.

\section{X-Ray Fluorescence}

Major elements (determined as the oxides with the exception of sulphur) and certain minor elements were analyzed by X-ray fluorescence analysis, using equipment at Durham University. The samples were crushed, washed with distilled water, and dried. The X-ray equipment used was a Philips PW1212 automatic spectrometer in conjunction with a Torrens Industries TE 108 automatic sample loader. Elemental line intensities were measured with respect to igneous and sedimentary rocks of established composition, including several wellknown international standards. A computerized massabsorption correction procedure was applied to the lineintensity data for the major elements (see Holland and Brindle, 1966), but only a simple peak-to-background ratio method was used for the trace-element intensity data. Calibration curves for the elements were then obtained and from these the composition of the unknown samples was determined.

\section{RESULTS}

The X-ray diffraction data are shown in Table 1 . Clearly the claystones and sandstones comprise variable but dominant (except Sample 315A-29-1, 31-33 cm) amounts of montmorillonite-group clays, plus illite, and locally quartz, anatase, clinopyroxene, and clinoptilolite. Quartz-filled radiolarian molds and clinopyroxene are optically recognizable in some smear slides. The montmorillonites fall into three groups: one is very crystalline, giving a strong peak at $15 \AA$ (in acetone) which expands to $17 \AA$ on glycolation; another is very poorly crystalline and very difficult to glycolate; the last is intermediate in crystallinity and is associated with a mixed-layer clay. Illite varies slightly in its crystallinity 
TABLE 1

X-Ray Diffraction Data From Basal Sediments at Hole 315A

\begin{tabular}{|c|c|c|c|c|c|c|c|c|c|c|c|c|c|c|}
\hline $\begin{array}{l}\text { Sample } \\
\text { (Interval } \\
\text { in } \mathrm{cm} \text { ) }\end{array}$ & Color & Smectite & Quartz & Calcite & Goethite & Hematite & Chlorite & Kaolinite & Pyroxene & Feldspar & Illite & Magnetite & Anatase & $\begin{array}{l}\text { Clinop- } \\
\text { tilolite }\end{array}$ \\
\hline $28-3,40-41$ & $\begin{array}{l}\text { Moderate red-brown } \\
\text { claystone with small } \\
(2-3 \mathrm{~mm}) \text { brown } \\
\text { concretions }\end{array}$ & $\begin{array}{l}\text { Poorly crystalline } \\
\text { montmorillonite } \\
\text { plus mixed-layer } \\
\text { clay }\end{array}$ & $30 \%$ & Absent & Absent & Absent & Absent & Absent & Absent & Absent & $20 \%$ & Absent & Absent & Present \\
\hline $28-3,104-106$ & Blue-green claystone & $\begin{array}{l}\text { Montmorillonite } \\
\text { dominant plus } \\
\text { mixed-layer clay }\end{array}$ & $10 \%$ & Absent & Absent & Absent & Absent & Absent & Absent & Plagioclase & $30 \%$ & Absent & Absent & Absent \\
\hline $29-1,31-33$ & $\begin{array}{l}\text { Grayish-blue-green } \\
\text { to dusky blue-green } \\
\text { claystone }\end{array}$ & $\begin{array}{l}\text { Montmorillonite } \\
\text { plus mized-layer } \\
\text { clay }\end{array}$ & $30 \%$ & Absent & Absent & Absent & Absent & Absent & Absent & Labradorite & $50 \%$ & Absent & Absent & Absent \\
\hline $29-1,105-108$ & $\begin{array}{l}\text { Grayish-blue-green } \\
\text { to dusky blue-green } \\
\text { claystone }\end{array}$ & $\begin{array}{l}\text { Montmorillonite } \\
\text { dominant plus } \\
\text { mixed-layer clay }\end{array}$ & Absent & Absent & Absent & Absent & Absent & Absent & $\begin{array}{l}\text { Trace } \\
\text { amount }\end{array}$ & Plagioclase & Present & Absent & Absent & Absent \\
\hline $29-1,120-122$ & $\begin{array}{l}\text { Grayish-green } \\
\text { volcanogenic } \\
\text { sandstone }\end{array}$ & $\begin{array}{l}\text { Very crystalline } \\
\text { montmorillonite } \\
\text { dominant }\end{array}$ & Absent & Absent & Absent & Absent & Absent & Absent & Present & Absent & $30 \%$ & Absent & $\begin{array}{l}\text { Trace } \\
\text { amount }\end{array}$ & Absent \\
\hline $30-1,58-60$ & $\begin{array}{l}\text { Grayish-green } \\
\text { volcanogenic } \\
\text { sandstone }\end{array}$ & $\begin{array}{l}\text { Very crystalline } \\
\text { montmorillonite } \\
\text { dominant }\end{array}$ & Absent & Absent & Present & Absent & Absent & Absent & Present & Labradorite & $20 \%$ & Absent & Present & Absent \\
\hline $30-1,65-66$ & $\begin{array}{l}\text { Grayish-red to very } \\
\text { dusky red claystone }\end{array}$ & $\begin{array}{l}\text { Poorly crystalline } \\
\text { montmorillonite } \\
\text { plus mixed-layer } \\
\text { clay }\end{array}$ & Absent & Absent & Present & Absent & Absent & Absent & Present & Labradorite & $30 \%$ & Absent & $\begin{array}{l}\text { Trace } \\
\text { amount }\end{array}$ & Absent \\
\hline $30-1,103-104$ & $\begin{array}{l}\text { Grayish-red to very } \\
\text { dusky red claystone }\end{array}$ & $\begin{array}{l}\text { Poorly crystalline } \\
\text { montmorillonite } \\
\text { plus large amounts } \\
\text { of mixed-layer clay }\end{array}$ & Absent & Absent & Present & Absent & Absent & Absent & Present & Labradorite & $20 \%$ & Absent & $\begin{array}{l}\text { Trace } \\
\text { amount }\end{array}$ & Absent \\
\hline $30-2,132-134$ & $\begin{array}{l}\text { Moderate reddish- } \\
\text { brown to dark } \\
\text { reddish-brown } \\
\text { claystone }\end{array}$ & $\begin{array}{l}\text { Very crystalline } \\
\text { montmorillonite } \\
\text { dominant plus } \\
\text { mixed-layer clay }\end{array}$ & $20 \%$ & Absent & Absent & Absent & Absent & Absent & Absent & Absent & $20 \%$ & Absent & Absent & Absent \\
\hline
\end{tabular}


from sample to sample and is most crystalline in 315A$29-1,31-33 \mathrm{~cm}$ where it is dominant over montmorillonite. In this sample and in 315A-28-3, 40-41 cm free crystalline quartz is present up to $30 \%$ by weight; this is reflected in the chemical analyses and is presumably related to the local abundance of quartzfilled radiolarian spheres. Opaline silica occurs in some samples. Despite the red color of certain of these sediments hematite was not detected; goethite was, however, identified in three samples including a grayishgreen sandstone. The high level of X-ray fluorescence in $315 \mathrm{~A}-28-3,40-41 \mathrm{~cm}$ and 315A-30-2, 132-134 cm suggests that most of the iron in these samples is held as $\mathrm{X}$-ray-amorphous oxide-hydroxides.

The major- and minor-element analyses are presented in Tables 2 and 3. When compared with the analyses of modern and ancient spreading-ridge sediments and with average Pacific deep-sea clays, the 315A claystones and sandstones show features in common with both, but match neither. Spreading-ridge sediments are characterized by $\mathrm{Fe}$ contents of about $15 \%-20 \%$ and accompanying Mn values of $2 \%-6 \%$; their $\mathrm{Al}$ values (ca $0.5 \%$ ), and Ti values (ca $0.02 \%$ ) are abnormally low (Boström and Peterson, 1969). Clearly the 315A sediments with average $\mathrm{Fe}$ contents of ca $8.5 \%$, Mn contents of ca $0.4 \%$, Al contents of ca $5.6 \%$, and Ti contents of ca $1 \%$ are chemically very different. Furthermore, the trace-metal contents of the 315A samples are low compared with Pacific spreading-ridge sediments (Boström and Peterson, 1969; Drever, 1971; Cronan, 1973). Even when compared with Pacific deep-sea clays (Goldberg and Arrhenius, 1958; Cronan, 1969), the 315A sediments are but humbly endowed with most trace elements; the $\mathrm{Si}$ values are, however, roughly comparable and the $\mathrm{Al}$ values are only slightly lower. The Mn contents are also roughly the same, but the $\mathrm{Na}$ values are notably lower in the multicolored claystones and volcanogenic sandstones. However, with respect to the iron and titanium contents, the claystones and sandstones are certainly the richer (cf. Cronan, 1969), with average Fe values of $8.5 \%$ (cf. $\sim 5 \%$ in pelagic clays) and $\mathrm{Ti}$ values of around $1 \%$ (cf. $0.45 \%$ in pelagic clays). Thus, the description of the basal claystones and sandstones as "iron-titanium-rich" is considered appropriate.

\section{CONCLUSIONS AND IMPLICATIONS}

Clearly the basal blue, green, and red sediments from the Line Islands Hole $315 \mathrm{~A}$ are not akin to Pacific pelagic clays derived from the usual intra-oceanic and aeolian sources. Neither are they comparable with spreading-ridge sediments. Their chemistry is presumably governed by the composition of component clay minerals, silica-filled radiolarian spheres, and of more or less degraded igneous material. Analyses of the underlying basalts (Jackson et al., this volume) support this contention. The high titanium values, for example, are related to the presence of detrital pyroxenes and authigenic anatase (Goldberg and Arrhenius, 1958); the iron presumably owes its origin to pyroxene and other altered ferromagnesian minerals.

TABLE 2

Major-Element Analyses of Basal Sediments at Hole 315A

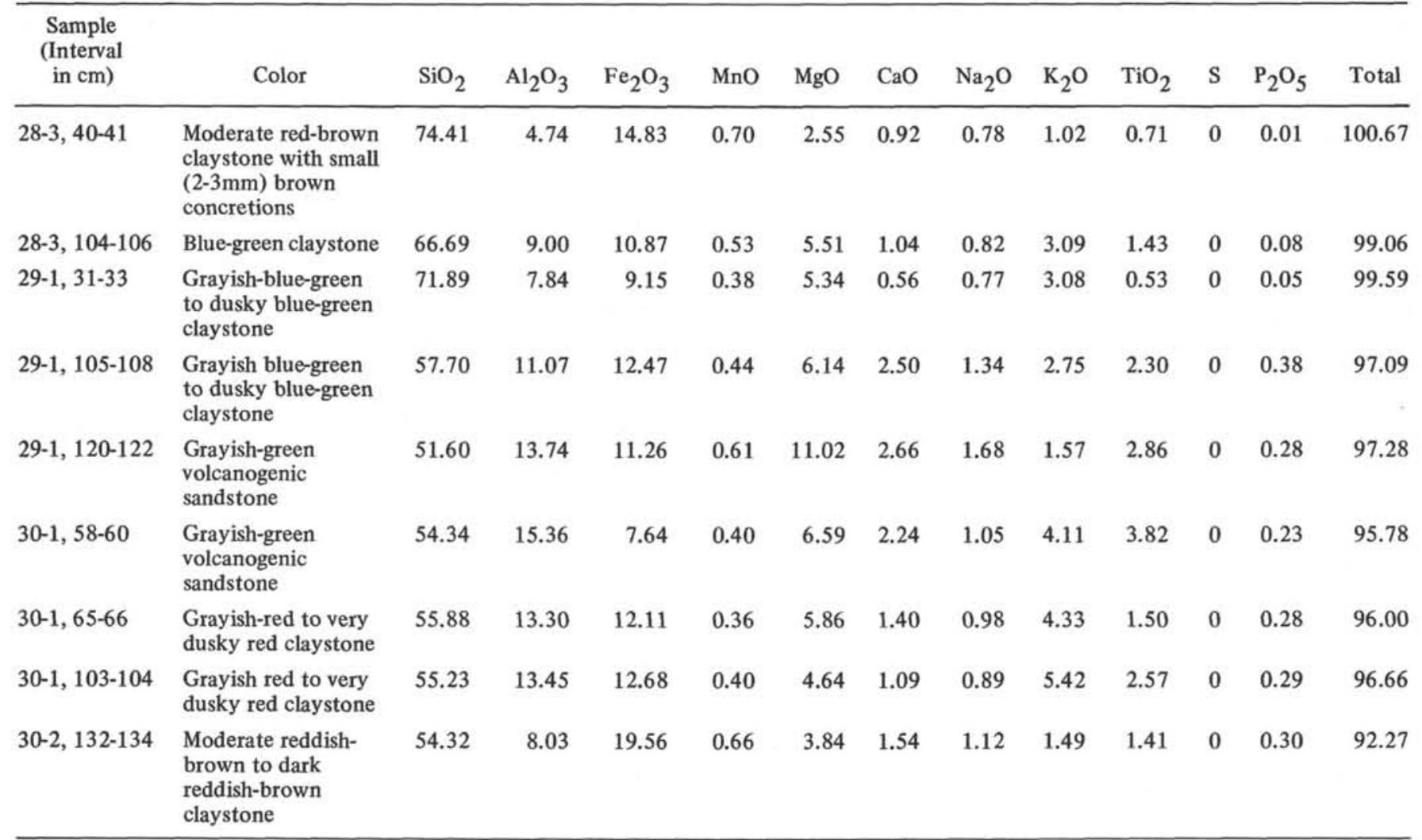


TABLE 3

Minor-Element Analyses of Basal Sediments at Hole 315A

\begin{tabular}{lrrrrrrrrrrrr}
\hline $\begin{array}{l}\text { Sample } \\
\text { (Interval } \\
\text { in cm) }\end{array}$ & $\mathrm{Ba}$ & $\mathrm{Nb}$ & $\mathrm{Zr}$ & $\mathrm{Y}$ & $\mathrm{Sr}$ & $\mathrm{Rb}$ & $\mathrm{Zn}$ & $\mathrm{Pb}$ & $\mathrm{Cu}$ & $\mathrm{Ni}$ & $\mathrm{Cr}$ & $\mathrm{Co}$ \\
\hline $28-3,40-41$ & 476 & 13 & 73 & 35 & 143 & 36 & 146 & 30 & 355 & 27 & 31 & 93 \\
$28-3,104-106$ & 64 & 15 & 136 & 18 & 179 & 102 & 60 & 10 & 78 & 38 & 54 & 27 \\
$29-1,31-33$ & 94 & 8 & 68 & 18 & 108 & 103 & 72 & 5 & 170 & 32 & 44 & 27 \\
$29-1,105-108$ & 63 & 21 & 191 & 44 & 220 & 71 & 114 & 19 & 64 & 43 & 63 & 25 \\
$29-1,120-122$ & 0 & 23 & 198 & 28 & 232 & 21 & 126 & 14 & 3 & 109 & 183 & 60 \\
$30-1,58-60$ & 0 & 4 & 125 & 13 & 130 & 31 & 83 & 0 & 89 & 24 & 318 & 28 \\
$30-1,65-66$ & 294 & 36 & 280 & 49 & 154 & 76 & 110 & 0 & 127 & 35 & 66 & 0 \\
$30-1,103-104$ & 363 & 26 & 232 & 36 & 133 & 83 & 83 & 11 & 221 & 15 & 73 & 0 \\
$30-2,132-134$ & 267 & 20 & 214 & 75 & 176 & 50 & 302 & 74 & 143 & 129 & 24 & 35 \\
\hline
\end{tabular}

The chemistry of these basal $315 \mathrm{~A}$ sediments indicates they were not formed from rocks of the oceanic-ridge type (Winterer, this volume; Jackson and Schlanger, this volume). The formation of metal-rich spreading-ridge sediments is assumed to depend on the action of geothermal systems involving circulating sea water and nascent oceanic crust (e.g., Corliss, 1971; Hart, 1973; Spooner and Fyfe, 1973). Thus, if the Line Islands represent a simple relict oceanic ridge, its geothermal system never became operative. Furthermore, the Line Islands volcanic rocks are not typical ocean-ridge tholeiites, but match more alkalic oceanic-island basalts (Jackson et al., this volume).

The only Pacific basal sediments known to us that resemble those from the Line Islands are red claystones reported by Natland (1973) from above the altered volcanics of Meiji Guyot in the northwest Pacific. It is significant that this guyot is part of a linear volcanic chain: that is, the Emperor Seamounts. The sediments here, although not analyzed for $\mathrm{Ti}$, are comparable in their $\mathrm{Fe}$ and $\mathrm{Mn}$ contents with the 315A material and are equally scanty in their trace-element levels. The implication is, therefore, that the deposits directly overlying volcanic seamounts constitute a distinct type of basal sediment essentially derived only from submarine weathering of basalt, and where geothermal systems and "hydrothermal solutions" play a negligible role.

\section{ACKNOWLEDGMENTS}

We are grateful to Harry Cook, Dale Jackson, Kerry Kelts, and Jerry Winterer for profitable discussions, and to Mrs. C.L. Mines for typing the manuscript. H. Jenkyns gratefully acknowledges financial support from the Astor Foundation.

\section{REFERENCES}

Boström, K. and Peterson, M.N.A., 1966. Precipitates from hydrothermal exhalations on the East Pacific Rise: Econ. Geol., v. 61., p. 1258-1265.

1969. Origin of aluminium-poor ferromanganoan sediments in areas of high heat flow on the East Pacific Rise: Marine Geol., v. 7, p. 427-447.

Cook, H.E., 1972. Stratigraphy and sedimentation. In Hayes, J.D. et al., Initial Reports of the Deep Sea Drilling Project, Volume 9: Washington (U.S. Government Printing Office), p. 933-943.

Corliss, J.B., 1971. The origin of metal-bearing hydrothermal solutions: J. Geophys. Res., v. 76, p. 8128-8138.
Cronan, D.S., 1969. Average abundances of $\mathrm{Mn}, \mathrm{Fe}, \mathrm{Ni}, \mathrm{Co}$, $\mathrm{Cu}, \mathrm{Pb}, \mathrm{Mo}, \mathrm{V}, \mathrm{Ce}, \mathrm{Ti}$ and $\mathrm{P}$ in Pacific pelagic clays: Geochim. Cosmochim. Acta, v. 33, p. 1562-1565.

, 1973. Basal ferruginous sediments cored during Leg 16, Deep Sea Drilling Project. In van Andel, T.H., Heath, G.R., et al., Initial Reports of the Deep Sea Drilling Project, Volume 16: Washington (U.S. Government Printing Office), p. 601-604.

Drever, J.I., 1971. Chemical and mineralogical studies, Site 66. In Winterer, E.L., Riedel, W.R., et al., Initial Reports of the Deep Sea Drilling Project, Volume 7: Washington (U.S. Government Printing Office), p. 601-604.

Gibbs, R.J., 1967. Quantitative X-ray diffraction analysis using clay mineral standards extracted from the samples to be analysed: Clay Minerals, v. 7, p. 79-90.

Griffin, O.G., 1954. A new internal standard for the quantitative X-ray analysis of shales and mine dusts: Research Rept. 101, Safety in Mines Research Establishment. Ministry of Fuel and Power. Sheffield, England, p. 25.

Goldberg, E.D. and Arrhenius, G.O.S., 1958. Chemistry of Pacific pelagic sediments. Geochim. Cosmochim. Acta, v. 13, p. 153-212.

Hart, R.A., 1973. A model for chemical exchange in the basalt-seawater system of oceanic layer II. Canadian J. Earth Sci., v. 10, p. 799-816.

Holland, J.G. and Brindle, D.W., 1966. A self-consistent mass absorption correction for silicate analysis by X-ray fluorescence: Spectrochim. Acta, v. 22, p. 2083-2093.

Natland, J.H., 1973. Basal ferromanganoan sediments at DSDP sites 183, Aleutian abyssal plain, and Site 192, Meiji Guyot, northwest Pacific, Leg 19. In Creager, J.S., Scholl, D.W., et al., Initial Reports of the Deep Sea Drilling Project, Volume 19: Washington (U.S. Government Printing office), p. 629-640.

Piper, D.Z., 1973. Origin of metalliferous sediments from the East Pacific Rise: Earth Planet. Sci. Lett., v. 19, p. 75-82.

Spooner, E.T.C. and Fyfe, W.S., 1973. Sub-sea metamorphism, heat and mass transfer: Contrib. Mineral Petrol., v. 42, p. 287-304.

von der Borch, C.C. and Rex, R.W., 1970. Amorphous iron oxide precipitates in sediments cored during Leg 5, Deep Sea Drilling Project. In McManus, D.A., Burns, R.E., et al., Initial Reports of the Deep Sea Drilling Project, Volume 5: Washington (U.S. Government Printing Office), p. 541-544.

von der Borch, C.C., Nesteroff, W.D., and Galehouse, J.S., 1971. Iron rich sediments cored during Leg VIII of the Deep Sea Drilling Project. In Tracey, J.I., Jr., Sutton, G.H., et al., Initial Reports of the Deep Sea Drilling Project, Volume 8: Washington (U.S. Government Printing Office), p. 829-835. 